\title{
Artificial Insemination in Dogs
}

\author{
Rita Payan-Carreira1 ${ }^{1}$ Sónia Miranda ${ }^{2}$ and Wojciech Niżański ${ }^{3}$ \\ ${ }^{1}$ CECAV - Univ. of Trás-os-Montes and Alto Douro, \\ ${ }^{2}$ Escola Universitária Vasco da Gama, \\ ${ }^{3}$ Univ. Environmental and Life Sciences, Wroctaw, \\ 1,2Portugal \\ ${ }^{3}$ Poland
}

\section{Introduction}

In Artificial Insemination (AI) the semen is collected manually from a stud male and thereafter deposited (inseminated) in the female so that fertilization can occur in the absence of natural mating. Artificial Insemination, one of the earliest techniques for assisted reproduction in animals and humans, took longer to be implemented in dogs due to speciesspecific particularities. In past decades, progresses in the knowledge of canine physiology and new advances in canine semen technology allowed these services to become available worldwide. Hence, subsequent to the increase in the artificial insemination demand among dog breeders and owners and the broaden of the AI to preserved semen as a management tool in canine breeding, as through international exchange of frozen semen, inbreeding within breeds can be reduced. Therefore, with spread of canine AI dog, breeders now may select stud dogs from all over the world to improve their kennel' genetics, without transport-associated stress to the animals. Also, it is possible to save semen from valuable dogs into sperm bank to be used in next generations, after their death or the peak of reproductive age. In addition, breeders also are aware of the sanitary benefits associated with AI. Avoiding direct contact between the male and female, AI also prevents the spread of sexually transmitted diseases, as those originated by Brucella canis or Herpes virus (Farstad, 2010; Linde Forsberg, 2005a).

Although the first reports on AI in dogs subsequent to the Spallanzani experiments (in late XVIII century) appeared by the end of the fifties, reporting the use of fresh semen, or in the sixties, the use of frozen semen, only in the nineties this technique was introduced into dog breeding practice, particularly in USA and Nordic countries (Foote, 2002; England \& Millar, 2008). The reproductive physiology of this species and unfavourable response of the dog sperm to freezing were the two major constraints to the initial efforts to improve the AI technique in dogs (Linde Forsberg, 2005a). A lot of research was performed in those areas, especially in the northern Europe, to overcome these issues, generating a large amount of information and allowing technical development, in particular in the canine semen technology. Nowadays, as a consequence of the demand for reproductive technologies, in particular the AI with fresh or refrigerate semen, this is a current service offered in the small animal veterinary practice. 
According to Linde-Forsberg $(2001,2005 a)$, from all the AI in dogs performed by veterinarians today in Europe, about $50-55 \%$ is done with fresh semen, collected at the clinic, $10 \%$ with chilled semen and around $35-40 \%$ with frozen semen. However, at least in Portugal, the use of imported chilled semen is far most frequent than the use of frozen semen when compared to other countries in Northern Europe.

Research on AI in the domestic dog, along with other reproductive technologies, proceed worldwide, particularly on sperm survival at freezing and the identification of deleterious components to spermatozoa or fertilization, providing important information for the preservation of wild canidae semen that are currently threatened or endangered.

\section{Indications for artificial insemination}

Several main indications exist to perform AI in the dog (Linde Forsberg, 2005a; England \& Millar, 2008; Farstad, 2010). In parallel, some ethical conditions must be discussed when facing the different interests of specific groups, namely dogs, breeders, owners and veterinarians.

Main indications for AI in dogs include both medical and breeding-management reasons (Table 1). As major potential advantage, AI may allow to reduce physical distances, the use of genetically valuable stud dog semen all over the word, fighting the stress of transportation of animals and inbreeding (Johnston et al., 2001; Linde-Forsberg, 2005a). It is also an important technique whenever physical and behavioural abnormalities in the male or female preventing natural mating (Table 2).

\section{The ethics and role of artificial insemination in canine breeding programs}

Performing canine AI may raise some ethical concerns, mostly to central institutions like the National Kennel Clubs or Veterinarian Orders or equivalent, in particular on what concerns the use of frozen semen and the need for intra-uterine insemination, mainly those involving surgical procedures. In fact, several countries (such as Norway, Sweden and the United Kingdom) refer to welfare concerns and discourage or even forbid the use of surgical procedures to obtain intra-uterine insemination (England \& Millar, 2008; Linde-Forsberg, 2005b).

Ethical issues are seldom associated with the non-surgical process of artificial insemination per se. Most procedures used for semen deposition are neither detrimental to the bitch, nor interfere with animal welfare, and even allow protection against certain diseases. However, some attention may be given to the inbreeding of animals that may compromise health of following generations (England \& Millar, 2008).

Restrictions to the use of AI in animals that never matted despite all physiological conditions met together to guarantee a successful mate, may respond to the ethical issue that demands for ruling out clinical reasons for $\mathrm{AI}$, as an underlying unaware problem (congenital or behavioural) may exists. This concern is in fact previewed in the Fédération Cynologique International (FCI) breeding rules (http://www.fci.be/circulaires/102-2010annex-fr.pdf). According to those rules, AI should not be performed in animals not having at least one previous litter registered from natural service. Furthermore, AI to be a recognisable breeding technique must be performed by veterinarian or a specifically recognisable technician, which skills will avoid complications or adverse effects, as well as stress or risks of welfare infringements towards the animals, in particular the female. 


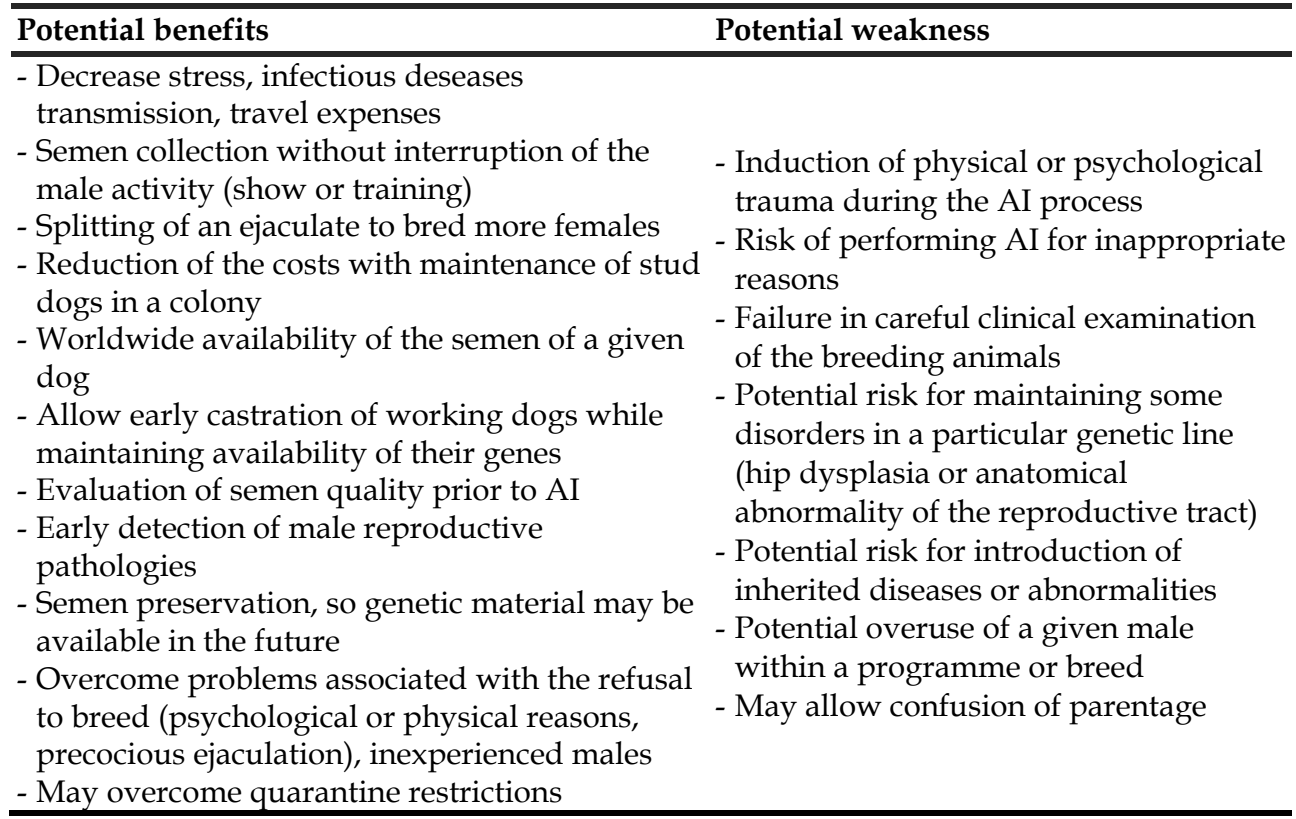

Table 1. Main advantages and inconveniences for canine AI.

\begin{tabular}{|c|c|}
\hline Factor & Cause \\
\hline Female-dependent & $\begin{array}{l}\text { - Male rejection } \\
\text { - Aggression } \\
\text { - Congenital abnormalities (e.g. presence of a vaginal septum; } \\
\text { genital tract strictures, small vulva and vagina) }\end{array}$ \\
\hline Male-dependent & $\begin{array}{l}\text { - Reduced libido (due to local or systemic diseases, age, deficient } \\
\text { breeding management, drugs) } \\
\text { - Pain } \\
\text { - Physical deficiency (such as inability to mount or to obtain } \\
\text { penile erection, lumbar muscle problems, congenital } \\
\text { abnormalities) }\end{array}$ \\
\hline $\begin{array}{l}\text { Associated to both } \\
\text { male and female }\end{array}$ & $\begin{array}{l}\text { - Inexperience } \\
\text { - Male to female disproportion } \\
\text { - Social and behavioural problems (dominant female, inversion of } \\
\text { the social hierarchy) }\end{array}$ \\
\hline
\end{tabular}

Table 2. Main causes for refusal of natural mating.

The competence of the operator to perform the procedures is essential to avoid all technique-related ethical constraints to the use of AI in dogs. Before offering canine AI services, practitioners ought to specialised themselves, acquiring profound knowledge of the reproductive physiology and pathology of the species and the skills to collect semen and to inseminate the female without risking animal health or welfare. 


\section{Semen collection and evaluation}

\subsection{Semen collection in the dog}

Semen collection in the dog is a relatively easy procedure, although requiring some training for optimization of the technique. Semen collection and evaluation is necessary to obtain good results in canine AI. Although practitioners are often asked to collect semen and perform AI without detailed semen analysis, every sample of semen collected should be evaluated (at least progressive forward motility, total sperm count and morphology) before it is used for artificial insemination or cryopreservation. Semen evaluation prior to insemination warrants the male potential fertility and consequently may predict the fertility potential for the AI. In addition, when preparing semen preservation, fertility certificate may be needed. In such cases andrological evaluation of the stud dog (breeding soundness evaluation or BSE) has to be performed. Semen collection should be performed before the physical exam or any stressful procedures on the stud, or can be booked to another day (Freshman, 2002; Johnston et al, 2001).

Semen can be collected from most dogs in the absence of a teaser, in a quiet and isolated room, where interruptions should be prevented, although the presence of a bitch would allow better ejaculates. In reluctant males, stimulating estrus scent can be provided by the presence of a female in estrus or by using frozen-thawed swabs or gauze sponges taken from vaginal secretions of estrus bitches (Freshman, 2002; Kutzler, 2005; Olson \& Husted, 1986). Although possible, not everyone achieves the use of a chemical pheromone (methyl phydroxybenzoate, Aldrich Chemical, Milwaukee, WI) swabbed on the perineal area and tail of an anestrus teaser (Johnston et al., 2001; Kutzler, 2005).

Collection of semen should be prepared in advance, and interval between collections or between the natural mating and collection, should be registered, if the male is regularly used. Ideal intervals between collections are 2 to 5 days, whilst intervals longer than 10 days may result in an increased number of morphological abnormalities and decreased motility (Freshman, 2002; Johnston et al., 2001). In longer periods, it is advisable to perform one previous collection, if semen is to be chilled or frozen for shipment. If semen preservation is planned, semen extender should be prepared before the arrival of the animal (Freshman, 2002).

The most common method for semen collection in the dog is by digital manipulation, in the presence of a female. However, bitch presence, although desirable as it facilitates procedures, is not essential to accomplish the collection (Farstad, 2010; Linde Forsberg, 2005a). It should be noticed that when the collection is achieved in the presence of the bitch ejaculates present higher concentration.

The use of manual massage is the most commonly used technique (Farstad, 2010; Johnston et al., 2001; Linde Forsberg, 2005a), although in the past semen was collected from dogs using an artificial vagina. Nowadays, semen collection into a tube is commonly accomplished by penile massage and the use of a cone or plastic sleeve, a funnel or a special collecting vial (Linde Forsberg, 2005a). Briefly, the process is started with a massage of the dog prepuce at the level of the bulbus glandis until developing partial erection, followed by the quick retraction of the prepuce and penile expose. If the collector is right-handed, semen must be collected from the dog's left side, with the operator holding the dog's penis with the right hand and the collection container in the left hand. During pelvic thrusting, rigid vials should be kept at a distance from the penis, to avoid trauma. When pelvic movements are finished and the dog lifts its rear leg, a $180^{\circ}$ backward rotation of the penis should be obtained and the erectile penis should then be directed into the collection cone or the funnel. 
Some pressure may be applied with the thumb on the apex of the glans penis, at the level of the urethral process, to stimulate ejaculation. When a crystal clear fluid (prostatic fluid) begins to flow into the collection tube, you can gently slide the collection cone off the penis. Watch for semen to flow in the collection tube (Farstad, 2010; Linde Forsberg, 2005a).

Canine ejaculate consists of 3 fractions, with the first and third fraction consisting of prostatic fluid and the second being rich in spermatozoa (England et al., 1990) (Table 3). The first fraction, the presperm portion, is emitted in 0.5 to 1 minute and is colourless, with a volume range of 1-5 $\mathrm{ml}$. It is expelled during first stage of erection, at the moment of the presence of evident copulatory movement of male. The second fraction, the sperm-rich portion, is also rapidly completed (1-2 minutes), and is grayish-white in colour, with a volume of 1-3 ml. It is expelled when thrusting movement of the male ceases and full erection is observed. The third fraction comes from the prostate and may be up to $30-40 \mathrm{ml}$; it may take up from 5 to 30 minutes to be completed (Günzel-Apel, 1994; Johnston et al., 2001).

\begin{tabular}{|c|c|c|c|}
\hline Characteristics & 1st fraction & 2nd Fraction & $3^{\text {rd }}$ Fraction \\
\hline Volume & $\begin{array}{l}0.1-2 \mathrm{~mL} \\
\text { (average } 0.33 \mathrm{~mL} \text { ) }\end{array}$ & $\begin{array}{l}0.1-3 \mathrm{~mL} \\
\text { (average } 1.17 \mathrm{~mL} \text { ) } \\
\text { Sometimes larger volume }\end{array}$ & $\begin{array}{l}1-2 \text { to }>20 \mathrm{~mL} \\
\text { Quite variable depending } \\
\text { on the animal. }\end{array}$ \\
\hline Colour & clear or opaque & $\begin{array}{l}\text { greyish-white, white, } \\
\text { milky-white }\end{array}$ & clear, transparent \\
\hline Consistency & watery & watery-milky, milky & watery \\
\hline Character & $\begin{array}{l}\text { prostate } \\
\text { secretion with } \\
\text { admixture of } \\
\text { epithelial cells, } \\
\text { urine, bacteria and } \\
\text { sperm cells }\end{array}$ & $\begin{array}{l}\text { sperm cells suspended in } \\
\text { seminal plasma }\end{array}$ & prostate gland secretion \\
\hline pH (average) & 6.37 & 6.10 & 7.20 \\
\hline Duration & $\begin{array}{l}\text { 5-90 sec. } \\
\text { (average } 13.5 \mathrm{sec} \text { ) }\end{array}$ & $\begin{array}{l}\text { 5-300 sec. } \\
\text { (average } 52.4 \mathrm{sec} \text {.) }\end{array}$ & $\begin{array}{l}60 \mathrm{sec}-20 \mathrm{~min} . \\
\text { (average } 6 \mathrm{~min} .55 \mathrm{sec} \text {.) }\end{array}$ \\
\hline
\end{tabular}

Table 3. Main characteristics of the different fractions of the dog ejaculate.

\begin{tabular}{cl}
\hline Size of the dog & \multicolumn{1}{c}{ Volume of the ejaculate } \\
\hline$<20 \mathbf{~ k g}$ & $\begin{array}{l}1-22.5 \mathrm{~mL} \\
\text { (average } 5.38 \mathrm{~mL})\end{array}$ \\
$>\mathbf{2 0 ~} \mathbf{k g}$ & $\begin{array}{l}2-45 \mathrm{~mL} \\
\text { (average } 12.75 \mathrm{~mL} \text { ) }\end{array}$ \\
\hline
\end{tabular}

Table 4. Variation on the volume of the ejaculate with the size of the dog (Dubiel, 2004)

In the dog, the volume of whole ejaculate varies between breeds (Table 4) mainly with animal size and is partially dependent on the volume of the third fraction collected, which constitute about $95 \%$ of the volume of the ejaculate in dogs (Farstad, 2010).

In most dogs, semen can be collected twice at 30 minutes interval (Farstad, 2010), although the second sample is usually slightly diluted. 
Most often, artificial insemination with freshly collected semen is performed without fractioning the ejaculate, although for artificial insemination, only the second fraction is of interest (Thomassen \& Farstadt 2009; Root Kustritz, 2003). Furthermore, it has been demonstrated the existence of detrimental effects on fertility when this fraction is not separated from the second one, particularly if semen will be processed as chilled or frozen. Consequently, ejaculate fractioning should always be accomplished, particularly separation of the third fraction. If the ejaculate has a very small volume, it may be diluted with semen extender, to facilitate its handling during insemination procedures.

\subsection{Semen assessment}

Semen assessment is an important part of the evaluation of fertility in males and it should be performed as routine element of prebreeding examination. Furthermore, semen evaluation ought to be completed before artificial insemination or sperm preservation. Semen should be assessed immediately after collection and it has to be handled carefully during all the procedures. Rapid changes of environmental temperature may be deleterious for spermatozoal motility and structure, and may also artifactually influence the results of examination. Any delay in semen assessment may decrease the percentage of motile sperm and simultaneously increase the percentage of dead sperm. It is advisable to keep all equipment necessary for semen collection and evaluation at the temperature near $37^{\circ} \mathrm{C}$ (Christiansen, 1984; Feldman \& Nelson, 1996; Linde-Forsberg, 1991).

On table 5, the most frequent indications for routine semen evaluation are presented. Semen evaluation is also frequently performed in the absence of known reproductive pathology, upon request of the owner. In addition, it can be performed at a predetermined moment after the diagnosis of a clinical disease that may have negative reflects on the potential fertility of a male dog.

It should be notice that reliable in vitro estimation of the real fertilizing ability of sperm cells is not always possible. Usually, in males with aspermic (no ejaculate), azoospermic (no spermatozoa), or necrospermic (no motile spermatozoa) semen, the fertilizing potential may be excluded. When the quality of semen in a dog with history of unsuccessful matings is low, premises exist to exclude such male from the breeding programme. However, it should always be remembered that the semen characteristics should be recheck 2-3 times at 1-2 weeks intervals, to confirm the male infertility. On the other hand, good in vitro semen quality does not always prove the fertilizing potential of a particular dog.

\section{Most frequent indications}

- Semen evaluation before artificial insemination

- Semen evaluation before/after chilling or cryopreservation

- Clinical signs of a disorder of male genital organs

- Whenever infertility or subfertility of a male is suspected

\section{Other situations, on request}

- New stud dog introduced to the breeding colony

- Evaluation of young stud dog before first mating

- In cases of serial unsuccessful matings of particular dog

- Pathological lesions of male genital tract observed by the owner

- Re-evaluation after the treatment of diseases of male genital tract

Table 5. Common reasons for canine semen assessment 
The semen assessment performed once is not always reliable, because:

- Frequent matings or semen collections may temporary result in a decreased semen quality;

- After a prolonged sexual rest dogs may ejaculate many dead, immotile spermatozoa of abnormal morphology;

- In young inexperienced males and dogs which mated earlier only naturally, without experience on semen collection, the obtained semen sample may contain only the part of sperm-rich fraction.

\subsubsection{Conventional assessment of semen}

Different approaches are available to assess the quality of the dog semen that can be grouped in conventional and advanced techniques. The later, usually requires more sophisticated means for the semen assessment and the support of a technical equipment, while the former may be performed in an inhouse lab.

The conventional approaches to semen evaluation include macroscopical evaluation of the semen (volume and colour), but also the microscopical assessment, which will give the concentration and the number of viable cells in the ejaculate.

\subsubsection{Macroscopic evaluation}

Volume. The volume of the ejaculate may be assessed in the calibrated tubes used for semen collection. It mainly dependends on the size of the dog, the size of the prostate gland, the animal age, the frequency of semen collection, the level of erotisation, and the volume of $3^{\text {rd }}$ fraction collected. A decrease of semen volume is observed in cases of benign prostatic hyperplasia, prostatic cysts, inflammatory lesions of prostate and testicles, inflammation of epididymis, vas deferens or urethra and at weak libido.

Colour. The colour of whole ejaculate depends on the volume of third fraction of ejaculate collected, on the concentration of spermatozoa per $\mathrm{mL}$ and the potential presence of nongerm cells in the ejaculate. When analysing the colour, one should be aware of the method of collection, as colour varies with the fraction to be analysed and the fact that analysis may been performed on the whole semen or on fractioned semen. The normal colour of whole ejaculate is greyish-white. Pathological colours include: green-greyish typical for the presence of the pus in semen; red or pink-specific for erythrocytes contamination (haemorrhages from urethra or corpora cavernosa, prostatitis); yellow specific for urine contamination; and brown, if in the presence of blood.

Any kind of semen contamination, such as hair or mud, exclude the specimen from further procedures including artificial insemination or semen preservation. It is therefore important to check the region of praeputial opening before semen collection and to clean it.

The presence of sediment consisting of sperm cells at the bottom of the tube is a normal feature if the semen is left for several minutes.

\subsubsection{Microscopic evaluation}

Motility. One of the most important step of conventional semen assessment is the subjective evaluation of progressively motile spermatozoa $(\mathrm{Spz})$ under contrast-phase microscope. The optimal temperature for assessment of dog sperm cell motility is $39^{\circ} \mathrm{C}$. A small drop of about $20 \mu \mathrm{L}$ of semen is placed on in a pre-warmed slide and cover by the coverslip. The evaluation is performed under the objective of $x 20$ to $x 40$. If the highly concentrated sperm- 
rich fraction is collected separately, the semen should be extended with saline or Tris-buffer to a concentration allowing the observation of particular, single sperm cells. The assessment is based on the evaluation of the average percentage of progressively motile spermatozoa in a few different fields of the specimen. The normal dog semen contains at least $70 \%$ of progressively motile spermatozoa (Feldman \& Nelson, 1996; Günzel-Apel, 1994).

A decrease in the percentage of motile spermatozoa may results from temperature shock, contamination with water, urine, blood or lubricants but also from long sexual abstinence and systemic or infectious diseases, such as brucellosis. Sperm agglutination is always pathological and is frequently found in cases of infectious diseases.

Concentration and total sperm count. The sperm concentration in whole canine normal ejaculate usually exceeds $80 \times 10^{6} \mathrm{Spz} / \mathrm{mL}$. If the second fraction of ejaculate is collected separately, the sperm cells concentration in sperm-rich fraction varies usually between $200-$ $600 \times 10^{6} \mathrm{Spz} / \mathrm{mL}$. It is generally assumed that the number of motile spermatozoa necessary for successful AI should be $>150 \times 10^{6}$ (Linde-Forsberg, 1991). Therefore, under normal conditions, the dog's ejaculate contains far more sperm cells than those needed for a seminal dose, although sometimes, especially in miniature or toy breeds, ejaculate volume and the total number of sperm cells are relatively low $\left(<100 \times 10^{6} \mathrm{Spz} / \mathrm{mL}\right)$. The concentration of spermatozoa in semen volume is usually assessed by cytometric method on the haemocytometer, such as the Thoma, Thoma-Neu, Bürker or Neubauer chambers, with semen pre-diluted at 1:200. In order to find the sperm count per $\mathrm{mL}$, the number of spermatozoa in the one or four large squares (depending of the chamber) is multiplied by 500 000. For the assessment of sperm concentration more sophisticated equipment could also be used, such as the spectrophotometer, flow cytometer or computer assisted semen analyser (Rijsselaere et al., 2005).

A large variety in the total number of spermatozoa per ejaculate is observed in different breeds. It varies between $50 \times 10^{6}$ up to $1575 \times 10^{6} \mathrm{Spz}$ (Linde-Forsberg, 1991; Oettle 1993). Small breeds do not produce as many spermatozoa as large breeds, as sperm cell production is related to the weight of the testicular tissue. The number of spermatozoa per ejaculate also varies according to age, testicular weight, sexual activity and the size of the dog (Amann, 1986). The total number of spermatozoa in the ejaculate may be decreased in young and older dogs and in inbred males. Apprehension, absence of the teaser bitch, painful prostate, spine rear limbs may also negatively influence the number of spermatozoa ejaculated.

Sperm morphology. The percentage of morphologically normal spermatozoa in canine semen should be greater than 70\% (Günzel-Apel, 1994). The morphology may be assessed under contrast-phase microscope, but usually the evaluation is performed under light microscope on stained slides. Smears of undiluted or diluted ejaculate are examined microscopically for the presence of structural abnormalities of spermatozoa. The stains used include modified Giemsa stain (DiffQuik) and Spermac ${ }^{\circledR}$ stain. The semen is smeared on a glass slide in a similar manner to that of blood, air dried and stained. The semen may be also stained with a nigrosin-eosin stain. A drop of this stain is gently mixed with a drop of semen on a pre-warmed slide before being smeared, and allowed to air dry. Evaluation of sperm morphology should be completed microscopically using oil immersion, using an objective of x100 or x 125. A minimum number of 200 spermatozoa should be counted and evaluated for the presence of abnormalities. The percentage of cells with particular morphological defects and of normal cells are calculated. Traditionally sperm cells abnormalities are divided into primary defects - originating from abnormalities of spermatogenesis and secondary defects - 
originating from abnormalities of semen maturation, transit through the ductal system and specimen preparation. According to another classification sperm abnormalities may be divided into major defects, negatively correlated with fertility, and minor defects, unassociated with fertility (Table 6) (Oettle, 1993).

\begin{tabular}{lll}
\hline Head & Primary spermatozoa defects & Secondary spermatozoa defects \\
\hline Neck & $\begin{array}{l}\text { Macrocephalus, microcephalus, } \\
\text { double, pointed, indented heads }\end{array}$ & $\begin{array}{l}\text { Free, bent heads, swollen acrosomes, } \\
\text { detaching acrosomes }\end{array}$ \\
\hline Midpiece & $\begin{array}{l}\text { Thickened, thinned, coiled, } \\
\text { kinked, double midpiece }\end{array}$ & $\begin{array}{l}\text { Bent midpiece, extraneous material } \\
\text { surrounding midpiece, proximal, mid } \\
\text { and distal cytoplasmatic droplets }\end{array}$ \\
\hline Tail & Thin, double, triple tail. & $\begin{array}{l}\text { Coiled, looped, kinked, folded, } \\
\text { detached tail. }\end{array}$ \\
\hline
\end{tabular}

Table 6. Main defects of the dog spermatozoa

The acrosomal status, which is frequently assessed for the estimation of the quality of the frozen-thawed semen, may be evaluated with the use of eosin-nigrosin, Giemsa, Trypan blue, Bismarck brown, Rose Bengal or Spermac ${ }^{\circledR}$ stainings (Dahlbom et al. ,1997; Dott \& Foster, 1972; Watson, 1975). When a spermatozoon presents more than one abnormality, it should be classified according to the most important abnormality or with the most prevalent one, if they have equal significance (Oettle, 1993).

'Live-dead' spermatozoa. The assessment of the percentage of live and dead spermatozoa is based on the assumption that dead spermatozoa possess disintegrated plasma membrane allowing eosin penetration. Thus the percentage of eosin positive cells stained with nigrosineosin stain is considered as percentage of dead cells. The normal dog semen consists of maximal percentage of $30 \%$ of dead sperm cells. The evaluation of the percentage of live and dead spermatozoa and the percentage of morphological defects may be performed on the same nigrosin-eosin stained slides.

\subsubsection{Advanced semen assessment}

In the past 2 to 3 decades, several strategies were developed to escape the subjectivity in the semen evaluation, related to the experience and skills of the observer, the method of specimen preparation, staining technique and number of cells evaluated, and wich is particularly important when the fertility potential of preserved sperm cells has to be ascertain. It is well documented that variations in results of the conventional evaluation of the same semen samples obtained by different observers and laboratories may reach 30-60\% (Coetzee et al., 1999; Davis \& Katz, 1992). Moreover, implementation of such methodologies, not routinely usable in the small to median veterinary clinics due to their costs, allows accurate comparisons between laboratories worlwide and minimizes occurence of large errors. Furthermore, advanced semen assessment is essential whenever the semen has to be preserved, in particular for freezing. Advanced semen assessment techniques are sumarized on table 7. In general, the results obtained with these methods are better correlated with the AI outcome than the results of traditional semen evaluation. 


\begin{tabular}{|c|c|c|c|}
\hline Tests & Aims & Procedure and Analysis & References \\
\hline $\begin{array}{l}\text { Hypo-osmotic } \\
\text { swelling test. }\end{array}$ & $\begin{array}{l}\text { Spz membrane } \\
\text { integrity } \\
\text { (indirect } \\
\text { method) }\end{array}$ & $\begin{array}{l}\text { Sperm incubation with hypo-osmotic } \\
\text { solutions for } 30 \text { minutes at } 37^{\circ} \mathrm{C} \\
\text { Spz with intact plasmalemma become } \\
\text { swolled and show coiled tails }\end{array}$ & $\begin{array}{l}\text { England \& } \\
\text { Plummer, 1993; } \\
\text { Kumi-Diaka, } 1993\end{array}$ \\
\hline $\begin{array}{l}\text { Computer } \\
\text { assisted sperm } \\
\text { analysis } \\
\text { [CASA] }\end{array}$ & $\begin{array}{l}\text { Objective } \\
\text { evaluation of } \\
\text { sperm cell } \\
\text { motility }\end{array}$ & $\begin{array}{l}\text { Determination of motility parameters } \\
\text { for individual spz } \\
\text { Characterization of Spz movement } \\
\text { according to the average velocity, the } \\
\text { trajectory, the amplitude of movement } \\
\text { and beat cross frequency. It allows } \\
\text { identification of Spz subpopulations }\end{array}$ & $\begin{array}{l}\text { Verstegen et al., } \\
2001 ; \\
\text { Rijsselaere et al., } \\
2003 ; \\
\text { Niżański et al., } \\
2009\end{array}$ \\
\hline $\begin{array}{l}\text { Zona } \\
\text { pellucida } \\
\text { binding assay }\end{array}$ & $\begin{array}{l}\text { Assessment of } \\
\text { sperm } \\
\text { fertilizing } \\
\text { potential }\end{array}$ & $\begin{array}{l}\text { - ZP-binding assay ( ZBA) using intact } \\
\text { homologous oocytes } \\
\text { - hemizona binding assay (HZA) using } \\
\text { bisected hemizonae } \\
\text { The number of spermatozoa bound to } \\
\text { ZP is counted with contrast-phase } \\
\text { microscopy. The number of bound Spz } \\
\text { reflects its fertilizing potential }\end{array}$ & $\begin{array}{l}\text { Hermansson et } \\
\text { al., 2006; } \\
\text { Kawakami et al., } \\
\text { 1998; } \\
\text { Rijsselaere et al., } \\
\text { 2005; } \\
\text { Ström-Holst et al., } \\
2001\end{array}$ \\
\hline \multirow{2}{*}{$\begin{array}{l}\text { Fluorescent } \\
\text { probes and } \\
\text { flow } \\
\text { cytometry }\end{array}$} & $\begin{array}{l}\text { Membrane } \\
\text { integrity and } \\
\text { evaluation of } \\
\text { live and dead } \\
\text { cells }\end{array}$ & $\begin{array}{l}\text { Combined use of several fluorescent } \\
\text { dyes (i.e, propidium iodide PI and } \\
\text { carboxyfluorescein diacetate, SYBR- } \\
\text { 14/PI) allow the identification of live } \\
\text { cells } \\
\text { Live cells activate fluorescence } \\
\text { (deacylation) which is maintained } \\
\text { intracellularly in intact membrane } \\
\text { cells. Dead Spz are stained red due to } \\
\text { the influx of PI through damaged } \\
\text { plasma membrane. }\end{array}$ & $\begin{array}{l}\text { Hewitt \& } \\
\text { England, 1998; } \\
\text { Peña et al., 1998; } \\
\text { Rijsselaere et al, } \\
\text { 2005; } \\
\text { P.F. Silva \& } \\
\text { Gadella, 2006 }\end{array}$ \\
\hline & $\begin{array}{l}\text { Capacitation } \\
\text { status }\end{array}$ & $\begin{array}{l}\text { Fluorescent antibiotic } \\
\text { chlorotetracycline (CTC), when bound } \\
\text { to free calcium ions, is fluorescent. } \\
\text { Combined with Hoechst } 33258 \text { allows } \\
\text { also assessment of percentage of live } \\
\text { cells and capacitation status } \\
\text { Three classes of sperm cells may be } \\
\text { assessed: uncapacitated and acrosome } \\
\text { intact (F-pattern), capacitated and } \\
\text { acrosome intact (B-pattern) and } \\
\text { capacitated and acrosome reacted (AR- } \\
\text { pattern) }\end{array}$ & $\begin{array}{l}\text { Guérin et al., } \\
\text { 1999; } \\
\text { Hewitt \& } \\
\text { England, 1998; } \\
\text { Petrunkina et al., } \\
\text { 2004; } \\
\text { Rota et al. 1999b }\end{array}$ \\
\hline
\end{tabular}




\begin{tabular}{|c|c|c|c|}
\hline Tests & Aims & Procedure and Analysis & References \\
\hline & $\begin{array}{l}\text { Acrosomal } \\
\text { status }\end{array}$ & $\begin{array}{l}\text { Lectins conjugated with fluorescein } \\
\text { isothiocyanate, such as Peanut } \\
\text { Agglutinin (FITC-PNA) or Pisum } \\
\text { Sativum Agglutinin (FITC-PSA). PNA } \\
\text { labelling is specific for the outer } \\
\text { acrosomal membrane whereas PSA is } \\
\text { labelling acrosomal matrix. } \\
\text { The absence of the fluorescence of the } \\
\text { living sperm indicates an intact } \\
\text { acrosome, whereas the presence of the } \\
\text { fluorescence is indicative for acrosome } \\
\text { disruption or acrosome reaction }\end{array}$ & $\begin{array}{l}\text { Kawakami et al., } \\
\text { 2002; } \\
\text { Peña et al., 2001; } \\
\text { Sirivaidyapong et } \\
\text { al., 2000; } \\
\text { P.F. Silva \& } \\
\text { Gadella, } 2006\end{array}$ \\
\hline & Mitochondria & $\begin{array}{l}\text { Rhodamine } 123 \text { (R123) is a } \\
\text { potentiometric membrane dye used for } \\
\text { the selective staining of functional } \\
\text { mitochondria. } \\
\text { It fluoresces only when the proton } \\
\text { gradient over the inner mitochondrial } \\
\text { membrane (IMM) is built up }\end{array}$ & $\begin{array}{l}\text { Garner et al., } \\
\text { 1997; } \\
\text { Gravance et al., } \\
2001\end{array}$ \\
\hline & $\begin{array}{l}\text { Integrity of } \\
\text { DNA structure }\end{array}$ & $\begin{array}{l}\text { - Sperm chromatin structure assay } \\
\text { (SCSA) with acridine orange (AO). } \\
\text { - Terminal deoxynucleotidyl } \\
\text { transferase-mediated nick end labeling } \\
\text { (TUNEL) } \\
\text { The SCSA is a flow cytometric method } \\
\text { for identification of changes in the } \\
\text { DNA status. AO shows green } \\
\text { fluorescence when DNA is intact and } \\
\text { red fluorescence when DNA is } \\
\text { denaturated }\end{array}$ & $\begin{array}{l}\text { Chohan et al., } \\
\text { 2006; } \\
\text { Bochenek et al., } \\
\text { 2001; } \\
\text { Garcia-Macis et } \\
\text { al, } 2006\end{array}$ \\
\hline
\end{tabular}

Table 7. Concise description of the available advanced methods for sperm quality assessment.

\section{Success rates for artificial insemination}

The key-issues to obtain good results by using canine artificial insemination are:

- Proper timing of the insemination

- The use of adequate number of viable sperm cells per dose

- Good semen preparation and handling

- Adequate deposition of semen in the female reproductive tract

On next sections the major issues on timing the AI and available techniques of semen deposition on the bitch genital tract will be discussed. 


\subsection{Timing the moment for insemination}

Obtaining successful pregnancies and adequate number of offspring per litter depends upon the correct timing for mating, as well as for insemination, particularly because bitches are mono-estrous, presenting usually one to two reproductive cycles per year. Although relationship among behavioral, hormonal and physiological events for the average bitch exists, considerable individual variation are also currently found on what concerns the duration of the estrogenic and early luteal stages (proestrus and estrus) and of the anestrus (Concannon et al., 1977; Concannon, 2004). The bitch usually presents a relatively long follicular phase and considerable variability exists in the onset of estrous behavior and acceptance of the male, making it difficult to determine occurrence of the LH surge and onset of ovulation in this species unless specific methods for timing the ovulation and estimating the fertile period are used (Linde-Forsberg, 1991). Furthermore, in this species, ovulation of immature oocytes (primary oocytes, before extrusion of the first polar body) determines the need for a maturation period in distal oviducts that may last for 96-108 hours (Concannon, 2004, 2010; Tsuitsui, 1989; Tsutsui et al., 2009); for most bitches, the secondary oocytes present a life span of 24-48h (Tsuitsui, 1989). Those particularities in the reproductive physiology may explain why the major cause for infertility in the bitch is the inappropriate breeding management (Goodman, 2001; Linde-Forsberg, 1991). Consequently, careful planning of mating time by timing ovulation is a key step in canine artificial insemination.

\subsection{Vaginal cytology and progesterone blood levels}

Determination of blood progesterone and the vaginal cell cornification on cytological specimens are the most widely used techniques (Linde Forsberg, 2003), to which recently has been added the vaginal endoscopy (that replaces the vaginoscopic exam) and the ultrasonographic follow-up of the follicular development and ovulation (England \& Concannon, 2002; Hewitt \& England, 2000; Fontbonne \& Malandain, 2006; Levy \& Fontbonne, 2007). These evaluations should be performed in sequence and with 2-3 days intervals for the majority of females (if the bitch has been reported to present short heat period, of about 6 to 9 days, is possible that daily evaluations may be needed).

On the vaginal cytology, epithelial cells of the vagina change their form in response to estrogen impregnation, and passes from small round cells with a clearly visible cytoplasm in non-estrogenic stages, to larger, cornified, angular shaped-cells with small pyknotic nucleus, almost to the point of disappearing, under the influence of estrogens (Figure 1). At beginning of estrus, vaginal cytology presents its maximum cornification index $(>70 \%)$. By that time, serial blood sampling for progesterone determination should start to detect the initial progesterone rise $(2-3 \mathrm{ng} / \mathrm{mL})$ which correlates with $\mathrm{LH}$ surge, which in turn triggers ovulation within 2 days. On the day of ovulation (day " 0 " of the cycle) progesterone concentrations may vary between 4 and $10 \mathrm{ng} / \mathrm{mL}$. The sudden increase in the number of round-shaped cells and of neutrophils reflects the onset of diestrus (Fontbonne \& Malandain, 2006).

Progesterone semi-quantitative immunoenzymatic assays are available for clinical routines, but although rapids, these test lack accuracy. They give progesterone concentration according to a colorimetric scale for values corresponding to basal progesterone levels (0-1 $\mathrm{ng} / \mathrm{mL}$ ), intermediate levels corresponding to the LH surge (around $1-2.5 \mathrm{ng} / \mathrm{mL}$ ) and the ovulation periods $(2.5-8 \mathrm{ng} / \mathrm{mL}$ ), and high progesterone levels (more than 8 or 10, 
depending on the kit). A recent study showed that, in dogs, semi-quantitative methods for progesterone determination are less accurate than the quantitative methods, in particular at intermediate plasma progesterone concentrations (Moxon et al., 2010). According to this study, the tested semi-quantitative assay estimated higher progesterone concentration than RIA (radioimmunoassay), which could suggest that the fertilization period had commenced earlier than it was actually the case. In addition to those assays, quantitative radio or chemiluminescent assays can also be used, even if not always available in the house lab, since cross-reactivity exist to the molecule between different species, for example with human progesterone.

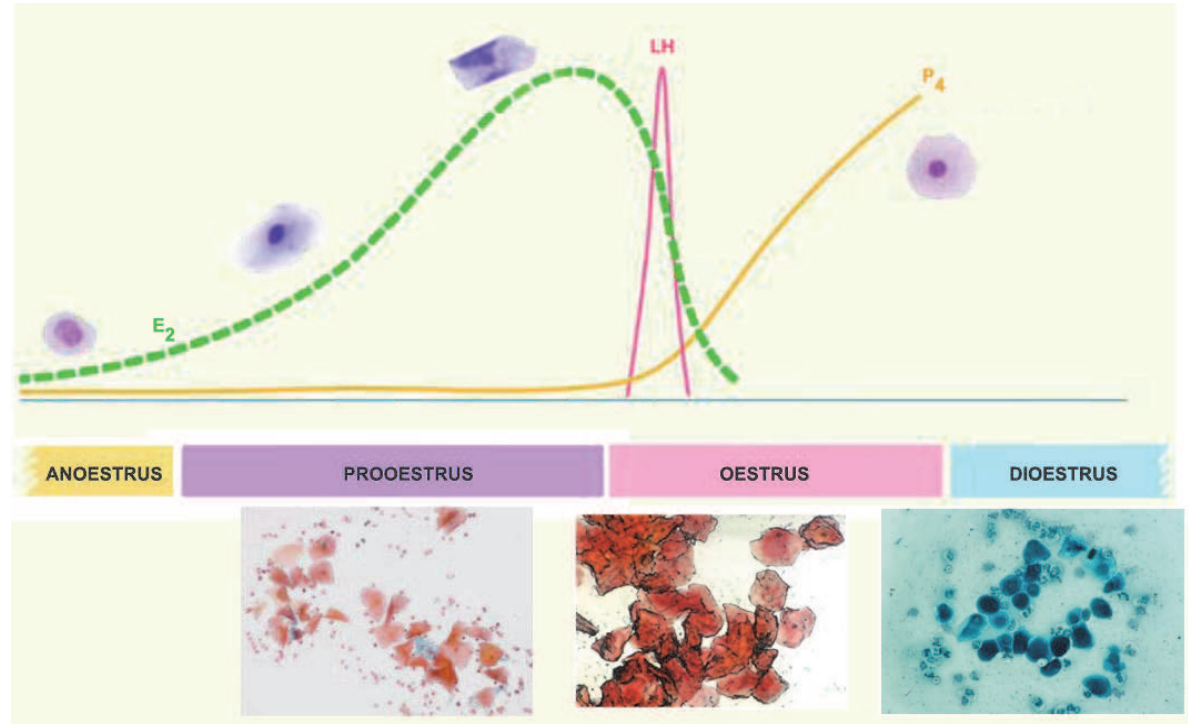

Fig. 1. Schematic representation of the major morphological changes of the predominant epithelial cell in the vaginal cytology during the dog estrous cycle. On the bottom, images of the vaginal péri-estrus cytological preparations stained with Harris-Shorr.

\subsubsection{Ultrasound examination}

Although ovarian ultrasound examination is a reliable and accurate method to determine ovulation in most domestic females, in the bitch fat accumulation in ovarian bursa that encloses the ovaries may difficult the value of the technique. In addition, several studies demonstrated that ultrasound images of the ovaries around ovulation are more difficult to analyze, due to the fact that ovarian follicles do not differ much in the immediate pre- and post-ovulatory period (England \& Concannon, 2002), as not all dog follicles collapse at ovulation (Yeager \& Concannon, 1996) and also because non-ovulated follicles frequently remain in the ovary (Wallace et al. 1992).

Consequently, follicular dynamics evaluation through ultrasonography (US) in dogs is still experimental and must follow a very precise protocol, which accuracy increase with the use of frequent examinations. In a recent study, Fontbonne (2008) reported that US was accurate enough to detect the occurrence of ovulation and obtain comparable numbers of ovarian structures between US examinations and macroscopic visual count on the surface of the 
ovaries after surgical removal, even if only one daily examination was performed. However, that author accepts that features of ovulation may be difficult to visualize in large breeds and in overweight animals. Pre-ovulatory follicles may present different aspects at US. Usually they appear as round to slightly triangular anechoic structures, sometimes slightly flattened, giving a honeycomb aspect to the ovary (Figure 2). At ovulation, different degrees of follicular collapse can be found in the US images, and usually a clear change of the ovarian echogenicity has been detected in a large number of bitches, giving the ovary a more homogeneous aspect (Fontbonne, 2008; Fontbonne \& Malandain, 2006). Persistence of non-ovulatory follicular structures was perceived in US images after ovulation. Also, in the immediate post-ovulation period, until 24 hours after US changes of the ovaries at ovulation, hypoechoic structures were observed in most cases (Figure 2). These structures were very similar to the pre-ovulatory follicles, although slightly smaller, and tending to increase in echogenicity (from the border to the interior of the structure) with time (Fontbonne, 2008; Fontbonne \& Malandain, 2006).
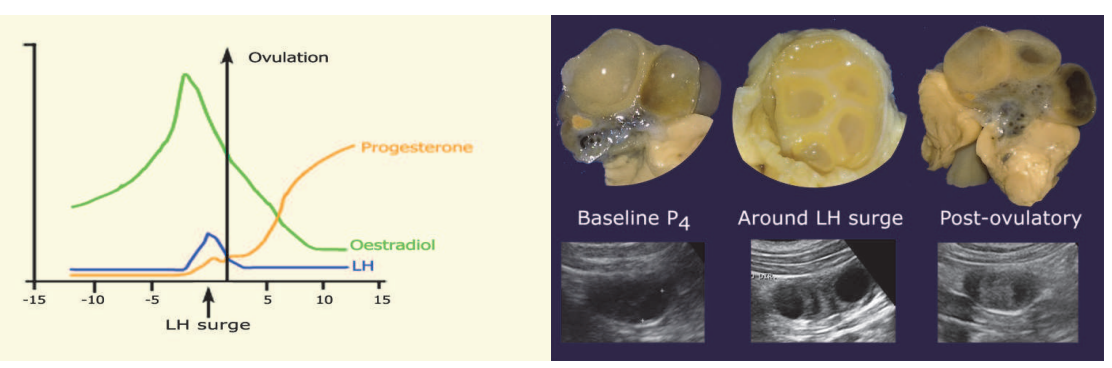

Fig. 2. Ultrasonographic scans of canine ovaries before and after LH surge and ovulation. US are compared with images of longitudinal sections of canine ovaries of similar stages of follicle developement.

\subsubsection{Vaginal endoscopy}

It is possible to use vaginal endoscopy to determine the fertile period although it does not allow accurate timing of ovulation. However, this method requires expensive equipment. Nevertheless, it may give a huge contribution to the vaginal evaluation and detection of anatomical abnormalities that may impair proper reproductive performance.

The fluctuation of estrogen and progesterone concentrations in the blood at consecutive stages of estrous cycle in the bitch results in specific morphologic changes of the vaginal mucosa. Analysis of these changes allows for exact assessment of the stage of the estrous cycle and for determination of the optimal insemination time (Goodman, 2001; Jeffcoate \& Lindsay, 1989; Lindsay 1983). The observation of the cranial part of the vagina is performed for this purpose. The deep introduction of the tip of endoscope into the narrow part of the vagina close to the cervix (dorsal median postcervical fold) or paracervix, is of less diagnostic value (Pineda et al., 1973).

Vaginoscopic examination is performed using a rigid endoscope 3-4 $\mathrm{mm}$ in diameter, with diagnostic sheath and a length of $30-33 \mathrm{~cm}$ or longer. The examination should be done on the standing animal. Usually there is no need of administration of sedatives. The tip of the endosope is introduced at the beginning at angle of $45-60^{\circ}$ cranially and dorsally. When the tip of the optics reaches the vagina it should be repositioned at horizontal axis. 
During proestrus the increase of the estrogen concentration results in the oedema of the vaginal mucosa. Vaginoscopy reveals rounded folds in the vagina. The mucosa of the folds is turgid, pink in colour and with a smooth surface. Normally the bloody discharge is also visible in the vagina. Sometimes, periodic blood outflow from the cervix, through the paracervix may be observed. The lumen of the vagina is narrow, which can be appreciated when the endoscope is advanced cranially. At the last days of proestrus and at beginning of estrus, the decrease of estrogen concentration and increase of progesterone $\left(\mathrm{P}_{4}\right)$ level is noted. It results in the collapse of vaginal folds. Formerly turgid and smooth, the mucosa, becomes wrinkled and shrunked. Vaginal folds become smaller. Maximal intensity of shrinkage of vaginal mucosa is observed between 3 and 7-8 days of estrous cycle. This time the loss of fluid from the tissue of vaginal mucosa and submucosa is great and the shape of vaginal folds become angulated with sharp angles at the top of folds. As the result, the lumen of the vagina is wider in comparison to proestrus. During diestrus vaginal folds become flat and round. The mucosa is red and small petechia may be visible at places touched by the tip of the endoscope. This is due to the fact that epithelium of the vagina is thin and consists of only 2-3 cell layers in diestrus and anestrus. An opaque, thick mucus is sometimes visible on the surface of epithelium (Figure 3).

\subsubsection{Proposed alternative methods}

Other methods has been proposed to monitor the bitch oestrous cycle, such as serial reading of the electrical resistance of the vaginal mucus around the time of ovulation, using probes inserted into the vagina during the heat period (Fontbonne, 2008), or the crystallization patterns in anterior vaginal fluids (England \& Allen, 1989) or in saliva (Pardo-Carmona et al., 2010), which have been found up not to present an acceptable reliabily in the identification of the canine ovulation.
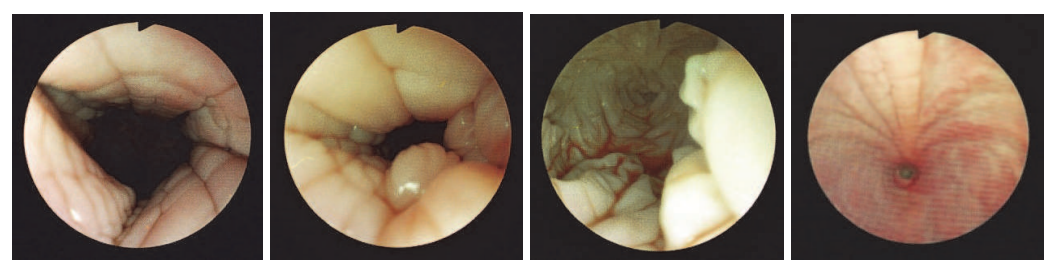

Fig. 3. Vaginal endoscopy of the bitch. [From left to right] Aspect of the vaginal folds at early proestrus, proestrus, estrus and diestrus.

\subsection{The moment for insemination}

In the bitch, when timing the day of ovulation as accurately as possible is essential to guarantee adequate fertility in natural mating systems, it becomes even more important to determine precisely when to inseminate bitches according to the sort of semen to be used (fresh, chilled or frozen semen), as usually semen longevity and sperm cells survival decreases with time. In addition, in frozen/thawed semen sperm cell capacitation is shorter due to secondary effects of the frozen procedure.

When fresh or chilled semen is used, insemination should be performed on the day of ovulation, and a second insemination must be schedule for 2 days later. On the contrary, when frozen/thawed semen is used, and considering the need of canine oocytes to mature in the oviducts, insemination should be performed 2 days after ovulation, and the second 
insemination 48h later (Figure 4). However, scheduling for the artificial inseminations may be slightly adjusted according to the experience of the operator, the place for semen deposition and the limitation on the number of inseminations. Consequently, regimes for canine AI may vary with authors (Root Kustritz, 2003). Table 8 condenses the available information on the AI schedules for fresh, chilled and frozen semen.

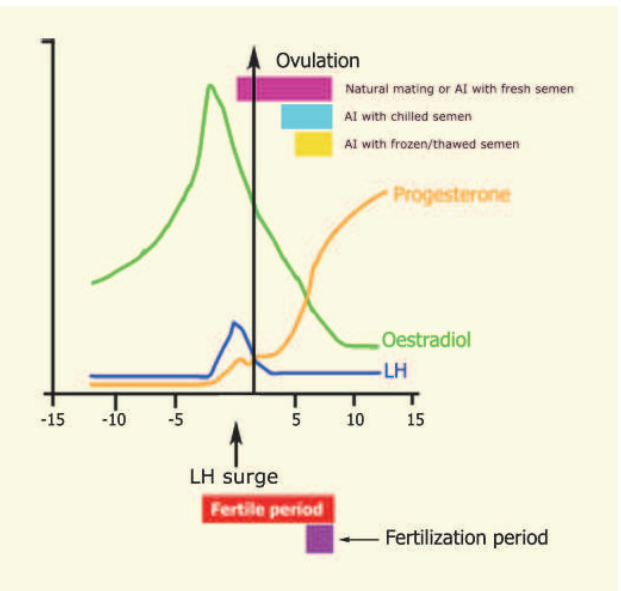

Fig. 4. Graphic representation of the fertile period and the ideal moment for canine AI according to the type of semen.

\begin{tabular}{|c|c|c|c|c|}
\hline Semen & Dosis & $\begin{array}{c}\text { Expected } \\
\text { spz } \\
\text { survival }\end{array}$ & Insemination schedule & $\begin{array}{l}\text { Expected } \\
\text { fertility }\end{array}$ \\
\hline Fresh & $\begin{array}{l}\text { 150-200x106 } \\
\text { spz/mL } \\
\text { (extended) }\end{array}$ & 4-6 days & $\begin{array}{l}\text { - Every other day, when } \mathrm{P}_{4} \\
\text { rise above } 4 \mathrm{ng} / \mathrm{mL} \text {, up to } \\
3 \text { times. } \\
\text { - Day } 1 \text { to } 4 \text { post-ovulation } \\
\text { - } \mathrm{P}_{4} \text { levels between } 8 \text { and } \\
15 \mathrm{ng} / \mathrm{mL}\end{array}$ & $\begin{array}{l}-80-90 \% \\
\text { (either with } \\
\text { transcervical } \\
\text { or vaginal } \\
\text { deposition) }\end{array}$ \\
\hline Chilled & $\begin{array}{l}150-200 \times 10^{6} \\
\text { spz/mL } \\
\text { (extended) }\end{array}$ & 24-72hrs & $\begin{array}{l}\text { - Breeding once or twice } 2- \\
4 \text { days post ovulation } \\
\left(\mathrm{P}_{4}=4-10 \mathrm{ng} / \mathrm{mL}\right) \\
\text { - Day } 2 \text { to } 4 \text { post-ovulation } \\
\text { - } \mathrm{P}_{4} \text { levels between } 8 \text { and } \\
\text { 15ng/mL }\end{array}$ & $\begin{array}{l}-80-90 \% \\
\text { (either with } \\
\text { transcervical } \\
\text { or vaginal } \\
\text { deposition) }\end{array}$ \\
\hline Frozen & $\begin{array}{l}50-300 \times 10^{6} \\
\text { spz/mL } \\
\text { (extended) }\end{array}$ & 12-24hrs. & $\begin{array}{l}\text { - Twice, at } \mathrm{P}_{4} \text { levels above } \\
\text { 8ng/mL and estrus } \\
\text { vaginal cytology } \\
\text { - Day } 5 \text { to } 7 \text { post-ovulation } \\
\text { - } \mathrm{P}_{4} \text { levels between } 18 \text { and } \\
28 \mathrm{ng} / \mathrm{mL}\end{array}$ & $\begin{array}{l}\text { - } 45 \% \text { if vaginal } \\
\text { deposition } \\
-67-84 \% \text { if } \\
\text { transcervical } \\
\text { or intrauterine }\end{array}$ \\
\hline
\end{tabular}

Table 8. Artificial insemination schedules for dogs, according to the type of semen used. 
If in the AI with fresh semen the success of the procedure is strongly related to the quality of semen used and the moment for AI (Table 9), when using chilled semen both the quality of semen and the site of semen deposition are important factors for success, whilst in the AI with frozen semen, the intra-uterine semen deposition is critical (Table 10).

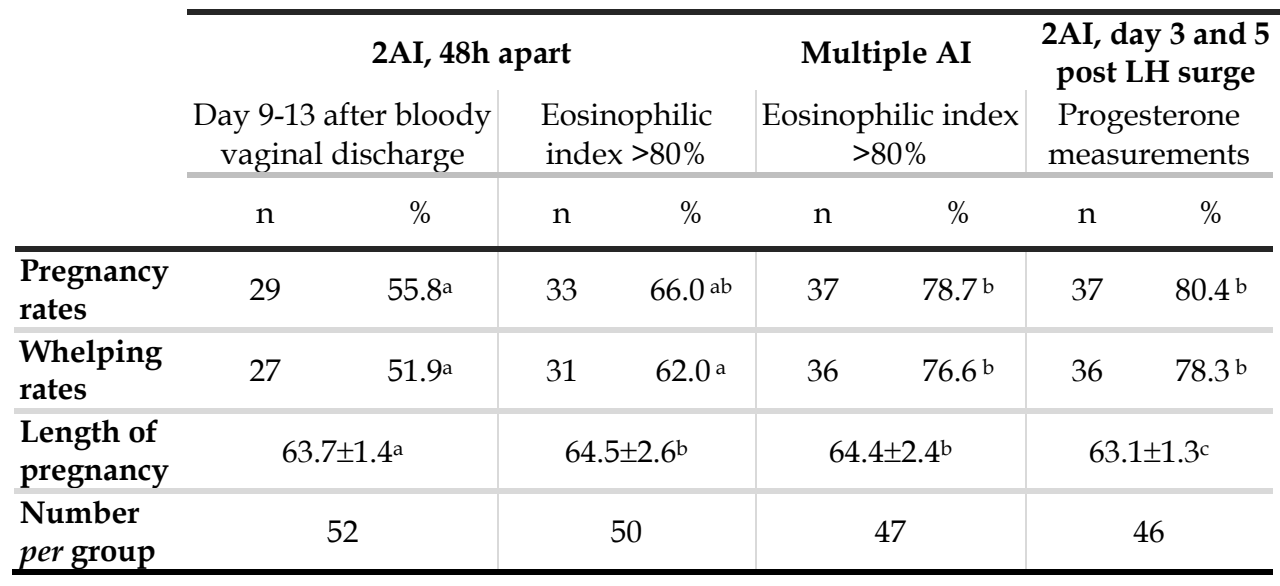

a,b,c - different superscript mean significant differences $(\mathrm{P}<0.05)$ between groups

Table 9. Success of canine AI with fresh semen according to the method used to timing AI $(\mathrm{n}=136)$ (Adapted from Niżański et al. 2005)

\begin{tabular}{c|c|c}
\hline \multirow{2}{*}{ Semen } & \multicolumn{2}{|c}{ Sperm deposition } \\
& Intra-vaginal (n) & Intra-uterine (n) \\
\hline Fresh & $47.7(1212)$ & $62(121)$ \\
\hline Chilled & $45.4(348)$ & $65.0(40)$ \\
\hline Frozen & $36.7(30)$ & $55.5(290)$ \\
\hline
\end{tabular}

Table 10. Comparison of whelping rates (\%) in vaginal and intrauterine inseminations according to the type of dog semen (n=2041) (Adapted from Linde Forsberg, 2002a).

\subsection{Insemination techniques}

In dogs, during natural mating, occurs the projection of a considerable portion of the ejaculate into the uterus, through the cervical canal, during the coital tie (England et al., 2006; Thomassen \& Farstad, 2009). When performing AI we should be aware that vaginal deposition per se will negatively influence sperm cell survival and their transport in the female genital tract, and therefore impairs ability to achieve normal whelping rates and/or litter sizes. However, deep vaginal insemination shows acceptable results when using fresh semen, and also to some extent for chilled semen. However, to obtain satisfactory success rates when using frozen/thawed semen, intra-uterine insemination is necessary.

As in other species, in dogs sperm cell number in the uterine lumen may be influenced by many factors, such as the moment of estrus, the type of breeding (natural mating or insemination) the method of insemination (intravaginal or intrauterine), the type of semen 
(fresh, chilled or frozen) and sperm quality (total and progressive motility and sperm speed), besides some individual variations (Rijsselaere et al., 2004). However, despite the influence of the intrauterine vs. vaginal insemination on the success of the procedure, once intrauterine insemination is achieve, the exact place of semen deposition is not of the main importance for the sperm distribution within the uterus (England et al., 2006; Rijsselaere et al., 2004). Consequently, no potential differences or advantages exist between the vaginal endoscopic approach and laparoscopy when the intra-uterine insemination is intended, as no differences were found in the deposition of the semen in the uterine body or the cranial tip of the uterine horns (Fukushima et al., 2010). Nevertheless, abdominal laparoscopy or surgery is strongly discouraged on the basis of animal welfare issues, as non-healthy related invading procedure that should be avoided.

Based on the last two years inseminations performed at the clinic (with a global success rate of around $75 \%$ ), using a comercial kit for progesterone determination, fresh semen and intra-vaginal deposition (2 AI, $48 \mathrm{~h}$ apart), it was found that when inseminations were performed with progesterone levels above $8 \mathrm{ng} / \mathrm{mL}$ a higher success rate and a closer to predicted whelping dates were achieved (Table 11), comparing to inseminations at lower levels of progesterone $(2.5-8 \mathrm{ng} / \mathrm{mL})$. No diferences were found in the litter size between these groups, which were very similar in age and parity of the bitches.

\begin{tabular}{|c|c|c|c|c|c|c|c|}
\hline Semen & \multicolumn{2}{|c|}{$\begin{array}{c}\text { Number of } \\
\text { animals }\end{array}$} & $\begin{array}{c}\text { Range of } \\
\text { age (mean) }\end{array}$ & $\begin{array}{l}\text { Progesterone } \\
\text { at AI }(\mathrm{ng} / \mathrm{ml})\end{array}$ & $\begin{array}{l}\text { Days from } \\
\text { last IA to } \\
\text { whelping }\end{array}$ & $\begin{array}{c}\text { Success rate } \\
\left(\mathrm{n}^{\circ} \text { females }\right. \\
\text { whelped } \\
\text { /inseminated) }\end{array}$ & $\begin{array}{c}\text { Liter size } \\
( \pm \text { SD) }\end{array}$ \\
\hline \multirow{2}{*}{ Fresh } & \multirow{2}{*}{39} & 18 & $\begin{array}{c}1-6 \text { years } \\
\text { (2.94 years) }\end{array}$ & $\begin{array}{l}2.5 \text { to } 8 \\
\mathrm{ng} / \mathrm{mL}\end{array}$ & 63 & 66.6 & $6.33 \pm 2.84$ \\
\hline & & 12 & $\begin{array}{c}\text { 1-6 years } \\
\text { (3.23 years) }\end{array}$ & $>8 \mathrm{ng} / \mathrm{mL}$ & 61 & 80.95 & $6.29 \pm 2.26$ \\
\hline Chilled & \multicolumn{2}{|c|}{42} & $\begin{array}{l}1-6 \text { years } \\
\text { ( } 3.6 \text { years) }\end{array}$ & $>8 \mathrm{ng} / \mathrm{mL}$ & 61 & 73.8 & $6.1 \pm 2.51$ \\
\hline
\end{tabular}

Table 11. Results for the AI procedures with fresh and chilled semen and 2 AI per animal, $48 \mathrm{~h}$ apart.

Independently of the place for semen deposition, repeating the AI at 24-48 hrs intervals results in a significantly higher fertility: for fresh semen both the pregnancy rate and litter size present a significantly increase when multiple AI are performed (Linde-Forsberg \& Forsberg, 1993), whilst for frozen semen the differences on the pregnancy rates are not significant, although litter size tended to increase with the number of inseminations (LindeForsberg, 2000, 2002a).

\subsubsection{Deep vaginal insemination}

Deep vaginal insemination is probably the widestly used method for insemination with fresh semen when the technique is performed by the breeder or in small budget clinics. For vaginal AI a simple plastic catheter of proper length may be used, to which a plastic disposable syringe containing the semen is attached. Or a commercial catheter in flexible latex tube presenting an inflatable balloon at the tip, like the Osiris gun, may be used; when inflated, this 
kind of device has the advantage of increasing the probability for intrauterine transport of the semen and of preventing semen backflow (Farstadt, 2010; Linde Forsberg, 2005a).

Before AI procedures start, cleaning of the perineal area, in particular the peri-vulvar area, is needed. As transabdominal palpation is usually used to guide or ascertain the vaginal catheter position, the owner of the female should be instructed to bring the animal with an empty stomach, which facilitates the procedure (Linde Forsberg, 2005a).

The bitch is placed in a standing position on an examination table or on the floor (according to the size of the female). To avoid catheterization of the urethra (the urethral opening in the bitch is located at the pelvic brim), particular attention should be paid not to unintentionally introduce into the urinary bladder. The insemination catheter is carefully introduced in the vagina of the bitch, first steeply upwards until the pelvic brim has been passed, and then in a horizontal angle, when it is carefully pushed further ahead (Farstad, 2010). In alternative, the vulva may be elevated to just below the anus (as the bitch does when stimulated by the male dog) (Linde Forsberg, 2005a). At this point, the position of the AI catheter must be learn by palpation, and orientated. If the catheter is in the urinary bladder, the cranial part of the vagina and the cervix may be palpable above the catheter and also the tip of the catheter stands out more clearly, due to the thinner walls of the urinary bladder in comparison to those of the vagina (Linde Forsberg, 2005a). After certification that the catheter is correctly placed, it is moved onward through the cranial portion of the vagina delimited by the dorsal medial folds. In smaller or primiparous bitches this point can be difficult to overcome, and may not be possible to pass the catheter into the cervical fornix. Except for those females, the AI catheter should be further introduced until it reaches the paracervical area, which can be palpated as a 1- to 2-cm-long, firm structure that ends at the cervix (a firm, rounded to ovoid structure, freely movable). The semen is deposited once the catheter has been located in the paracervical area, close to the external cervical os.

During AI the bitch is held with the hindquarters up and head down, in an angle of 45-60. This position facilitates transabdominal palpation of the cervix and ensures that the semen will not be expelled through backflow. According to earlier reports, the bitch should be maintained in the same position up to period of time varying from 5 to $20 \mathrm{~min}$ after AI. However, reducing the interval of elevated hindquarters to 1 min seems not affect fertility (Pinto et al., 1998). Also, feathering or stroking of the vulvar or perineal region is reported by several authors as form of stimulating the semen transport into the uterus, in an attempt to mimic the vaginal stimulation by the thrusting movements of the dog during natural mount. However, the contribution of such procedures to the exit of the technique has not been proven yet.

\subsubsection{Intrauterine insemination}

Intrauterine insemination may be performed by using non-surgical transcervical catheterisation (Linde-Forsberg, 1991; Linde-Forsberg and Forsberg, 1989, 1993; LindeForsberg et al., 1999) or by surgical semen deposition by laparotomy (Brittain et al., 1995; Günzel-Apel \& Thiet, 1990) or laparoscopy (L.D.M Silva et al., 1995, 1996). The majority of European centers working on small animal reproduction prefer transcervical intrauterine insemination (TCI) due to reasons associated with animal welfare. However, catheterisation of uterine cervix in the bitch is a difficult procedure and demand skill and experience. The semen of lower quality, such as frozen-thawed or that collected from subfertile dogs have to be deposited intrauterine to assure satisfactory results of artificial insemination (Linde- 
Forsberg et al., 1999; Thomassen et al., 2006). The conception rates after intravaginal insemination with frozen-thawed semen are significantly lower when compared with the results of intrauterine insemination.

\subsubsection{The Norwegian or Scandinavian technique}

The method of non-surgical transcervical intrauterine insemination was first time described in 1975 (Andersen, 1975). The technique has been adapted from the artificial insemination performed in foxes. Two catheters are used in this method - the outer plastic catheter and inner metal thin catheter. There are 3 sizes of the catheters, for small, medium and large breeds. The catheterisation should be made on standing animal. Sometimes there is no need for administration of sedatives, but usually a small dose of alpha-mimetic, such as medetomidine, is advisable for abdominal muscles relaxation. The outer plastic catheter should be introduced into the vagina. It should be advanced as far as is possible. In many bitches, especially those of larger breeds, the tip of the catheter passes into the cranial narrow part of vagina. However, in some smaller bitches the introduction of the outer catheter through the paracervix is difficult. It is necessary to palpate the end of the catheter and the cervix through the abdominal wall. The cervix is palpable at estrus as solid, ovoid structure. It is advisable to move the tip of the catheter ventrally towards the ventral region of abdominal wall. This procedure is helpful in palpation of the cervix. The inner metal catheter should be introduced through the plastic catheter. The cervix should be fixed between the thumb and other fingers and tilted to horizontal axis. The metal catheter is introduced into the cervical canal under the control of the position of the cervix by palpation through the abdominal wall (Andersen, 1975; Linde-Forsberg, 1991). This technique demands skill and experience. It is harder to perform uterine catheterisation in obese or nervous bitches and in giant breeds.

The scandinavian method of uterine catheterization is recommended for routine insemination of bitches (Ferguson et al., 1989; Günzel-Apel 1994; Linde-Forsberg, 1991, 1995). The use of this technique of insemination is especially advisable in cases when using of semen of lower quality due to male subfertility or sperm cryopreservation. LindeForsberg and Forsberg (1989) obtained 83.9\% and 69.3\% of pregnant bitches (data corrected for the stage of estrus) after insemination with fresh and frozen-thawed semen, respectively. The litter sizes were lower by $23.3 \%$, when frozen-thawed semen was used in comparison to fresh semen. Rota et al. (1999a) reported 25\% higher pregnancy rate after intrauterine semen deposition when using scandinavian technique than after vaginal semen deposition. On the basis of analysis of 327 inseminations Linde-Forsberg et al. (1999) concluded that success rate of scandinavian method and vaginal insemination with frozen-thawed semen was $84.4 \%$ and 58.9, respectively. Niżański (2006) proved that results of vaginal insemination with frozen-thawed semen are significantly lower in comparison with fresh semen, in spite of the use of modification of the technique of vaginal semen deposition, plasma addition and adjustment of the number of spermatozoa.

\subsubsection{Endoscope-assisted vaginoscopic method (New Zealand method)}

Intrauterine insemination of the bitch under the visual control of endoscopic equipment was first time described by Wilson (Wilson, 1993, 2001), using a rigid endoscope - cystouretroscope of the length $29 \mathrm{~cm}$ with diagnostic external sheath. The procedure is performed on the standing animal. Uterine catheterisation is made with the use of flexible catheter introduced into the working channel of the endoscope. The endoscope is introduced into the 
cranial narrow part of the vagina, while a flexible catheter is introduced cranio-dorsal into the external orifice of the cervical canal under the visual control performed through the endoscope. Usually it is not necessary to administer any sedatives.

The results for the intrauterine deposition of frozen-thawed semen when using this technique are quite satisfactory (Table 12). Wilson (1993), with the use of frozen semen, refers a pregnancy rate and litter size $83.3 \%$ and 7.5 puppies per litter, respectively. Niżański (2005) obtained whelping rates of $68.7 \%$ and $27.8 \%$, when frozen-thawed semen was deposited by intrauterine vaginoscopic method and by vaginal insemination, respectively. Results obtained by Linde-Forsberg et al. (1999) were poorer in comparison with the Scandinavian method. However, vaginoscopic intrauterine insemination is currently considered as the practical, modern and useful tool in assisted reproductive techniques in dogs which may become in the future the routine method of insemination.

\begin{tabular}{c|l|c|c|c|c}
\hline $\begin{array}{c}\text { Insemination } \\
\text { technique }\end{array}$ & $\mathbf{n}$ & $\begin{array}{c}\text { Whelping rate } \\
\text { (n }{ }^{\mathbf{0}} \text { females } \\
\text { whelped/inseminated) }\end{array}$ & $\begin{array}{c}\text { Litter size } \\
\text { at birth } \\
\text { (range) }\end{array}$ & $\begin{array}{c}\text { Litter size } \\
\text { at weaning } \\
\text { (range) }\end{array}$ & $\begin{array}{c}\text { Percentage of } \\
\text { male } \\
\text { pups/litter }\end{array}$ \\
\hline $\begin{array}{c}\text { Intravaginal, } \\
\text { using an } \\
\text { infusion pipete }\end{array}$ & 18 & $\begin{array}{c}27.8 \mathrm{a} \\
(5 / 18)\end{array}$ & $\begin{array}{l}3.0 \pm 1.2^{\mathrm{a}} \\
(2-5)\end{array}$ & $\begin{array}{c}2.6 \pm 0.9 \mathrm{a} \\
(2-4)\end{array}$ & $51.5 \pm 25.9 \mathrm{a}$ \\
$\begin{array}{c}\text { Intrauterine, } \\
\text { using the } \\
\text { endoscope }\end{array}$ & 16 & $\begin{array}{c}68.7 \mathrm{~b} \\
(11 / 16)\end{array}$ & $\begin{array}{c}4.9 \pm 1.7 \mathrm{~b} \\
(3-8)\end{array}$ & $\begin{array}{c}4.6 \pm 1.7 \mathrm{~b} \\
(2-8)\end{array}$ & $54.7 \pm 18.7 \mathrm{a}$ \\
\hline
\end{tabular}

Different superscripts in the same column indicate significant difference $(\mathrm{p}<0.05)$

Table 12. Whelping rate and mean litter size in bitches intravaginally or intrauterine vaginoscopically inseminated with frozen-thawed semen. AI were performed at $4^{\text {th }}$ and $6^{\text {th }}$ days of oestrous cycle.

Currently a large variety of rigid endoscopes of different brands is available. The most suitable are those of the length $30-35 \mathrm{~cm}$ with $30^{\circ}$ or $0^{\circ}$ view angle and the diameter of $3 \mathrm{~mm}$ or similar. Some companies market the equipment dedicated specifically for artificial insemination in bitches. The optics of endoscope should be used with outer sheath equipped with working channel allowing for introduction of flexible catheter of the diameter of 5-7 French gauge. The mechanism of Albaran is not useful in the endoscope for artificial insemination of bitches, as it is not practical and the diameter of the outer sheath becomes too large when it is attached.

The catheterization may be problematic in both toy and giant breeds. In the first case, the diameter of the equipment may be too large for introduction of the tip of optics near the uterine cervix, impairing visualization of external cervical orifice. In contrast, in giant breeds the length of the vagina may exclude the possibility to access the region of the cervix. One additional problem may be associated with the presence of the blood or mucus within the vagina. Sometimes the fluid present in the genital tract may cover the terminal lens of the endoscope making the observation impossible. Withdrawal the optics and cleaning of the lens is necessary in such cases. For better visualization of the vagina, especially within the cranial narrow part, insuflation with $\mathrm{CO}_{2}$ made with insuflator or even with rubber bulb is advisable. Therefore the view of tissues is focused, sharper and clearer, which makes the procedure easier. The time necessary for catheterization is variable. It depends mainly on 
the skill of the operator and on the anatomical features of the vagina, and varies usually between 0.5-3 minutes, but it may be longer. In nervous bitches the administration of small doses of sedatives, such medetomidine, is advisable, although in not too high doses, as the catheterisation should be done on standing bitch.

Currently the vaginoscopic method of intrauterine insemination appears to be advantageous and useful technique of semen deposition in the uterine lumen in bitches. The technique demands skill but it is practical and quick to perform for experienced operators. The visual control of introduction of the catheter into the uterus is the important advantage of the technique. The observation of the moments of semen deposition and control if there is no semen backflow is therefore possible. Moreover, it allows also uterine sampling when a female is suspected of infertility due to uterine disease (Thomassen \& Farstad, 2009). For these reasons this method of intrauterine insemination is becoming more popular.

\subsubsection{Surgical technique}

Surgical insemination technique have been proposed once for frozen semen or when the bitch presents an anatomical obstruction that prevents the insertion of the catheter or endoscope. Both the laparoscopic approach and the laparotomy requires anaesthesia and good surgical skills. The semen is introduced into the uterus by puncture of uterine wall or incision with a scapel and passage of a tom cat catheter (Farstad, 2010; Thomassen \& Farstad, 2009). However, in such methods, semen deposition is performed only once.

Some restrictions may exists to application of this method in different countries, that may compromise the registration of litters obtained without fulfilment of the legal requirements, such as previous evaluation of the situation or previous authorization of the local Kennel $\mathrm{Club}$ for the procedure. Furthermore, some ethical constraints have been raised regarding the use of surgical techniques for AI in dogs. Surgery is an invasive procedure, so it is unlikely to carry it out in the best interest of the animal, and the possibility of transmission of an undesirable trait in a particular animal genetic line should be kept in mind.

\section{Rules and regulations concerning the import or export of sperm}

Before implementing canine artificial insemination the owner and the clinician should be aware of the national or international regulations on semen import, if applicable, and of the local Kennel Club requirements respecting the use of canine AI and litter registration. In addition, procedures may differ between the use of national or imported semen. Consequently, attention should be paid well in advance to this matter.

In the absence of a specific national regulation, most Kennel Clubs follows FCI (Fédération Cynologique Internacionale) determinations for $\mathrm{AI}$, transposed to the FCI International Regulation for Breeding (http://www.fci.be/circulaires/102-2010-annex-fr.pdf). To ensure that ethical issues are minimised, FCI recommends that AI should only be done in healthy dogs with proven fertility (article number 13). In addition, in the introductory section of this regulation, FCI specifically limit the use of dogs presenting diseases possible to be transmitted to following generations and those presenting major, eliminatory defects in regard to the breed standard. Furthermore, it presumes that the AI is performed by a Veterinarian, which should certify the quality of the dog semen (either for the fresh and the processed semen, the later being certified in a standard document to be released upon semen collection and preservation) and also to attest the Kennel club to the occurrence of an AI for a specific female. In both documents, correct identification of the animals (either the 
male or female) is mandatory, and can be obtained through the use of a tattoo or a microchip. The time to submit the AI certificate may differ between national Kennel Clubs. In some countries the Club must be informed of the AI procedure within the first 2 weeks, whilst in others, only when the litter is to be registered.

Besides regulations on performing $\mathrm{AI}$ to a bitch, attention must be paid to issues concerning the semen collection and use. Besides the use of a recognisable male, with a certified pedigree, particular requirements may exist from national Kennel Clubs or the Official Agriculture entities, which may vary for chilled and frozen semen. In some situations the permit to import dog semen is required, which may or may not need to be accompanied by a DNA sample, and a health certificate that may include blood testing against the most important infectious or congenital canine diseases. Awareness of the latest official requirements is essential when considering semen international shipment. Additional information on the shipment regulations may be obtained throught the references Linde Forsberg, 2001, 2005b.

\section{Conclusion}

Demands for canine artificial insemination is growing worldwile together with an increase request for semen preservation in sperm banks. Furthermore, a tendency exists to increase the demands for the use of frozen/thawed semen over fresh semen AI, as part of breeding tools for genetic improvement. Nowadays is possible to achieve adequate whelping rates and litter sizes regardless of the type of semen used, as long as proper timing of AI and proper semen deposition are used. Client education and technical councelling must complete the AI services to be offered by specialized practicioners, in particular when breeding a problematic bitch.

\section{Acknowledgments}

The authors are greatly indebted to Dr Malgorzata Ochota for her valuable cooperation and thoughtful comments during language revision of this manuscript.

\section{References}

Amann R.P. (1986) Reproductive physiology and endocrinology of the dog, In Current therapy in theriogenology. 2nd edition, Morrow D.A. (ed), 523-538, W.B. Saunders Comp., ISBN 978-0721665801, Philadelphia.

Andersen K. (1975) Insemination with frozen dog semen based on a new insemination technique. Zuchthygiene, 10, 1-4.

Bochenek M., Smorąg Z., \& Pilch J. (2001) Sperm chromatin structure assay of bulls qualified for artificial insemination. Theriogenology, 56, 557-567.

Brittain D., Concannon P.W., Flanders J.A., Flahive W.J., Lewis B.L., Meyers-Wallen V., \& Moise N.S. (1995) Use of surgical intrauterine insemination to manage infertility in a colony of research German Shepherd dogs. Lab. Anim. Sci., 45, 404-407.

Chohan K.R., Griffin J.T., Lafromboise M., De Jonge C.J. \& Carrell D.T. (2006) Comparison of chromatin assays for DNA fragmentation evaluation in human sperm. J. Androl., 27, 53-59.

Christiansen I.J. (1984) Reproduction in the Dog \& Cat. Bailliere Tindall, ISBN 978-0702009181, London. 
Coetzee K., Kruger T.F., Lombard C.J., Shaughnessy D., Oehninger S., Ozgür K., Pomeroy K.O., \& Muller C.H. (1999) Assessment of interlaboratory and intralaboratory sperm morphology readings with the use of a Hamilton Thorne Research integrated visual optical system semen analyzer. Fertil. Steril. 71, 80-84.

Concannon P.W. (2004) Canine Breeding Management and Artificial Insemination: Techniques and Caveats, Proceedings of the 29th World Congress of WSAVA, Rhodes, Greece, 8-9 Oct. http://www.vin.com/proceedings/ Proceedings.plx?CID=WSAVA2004\&PID $=8745 \& \mathrm{O}=$ Generic

Concannon P.W. (2010) Reproductive cycles of the domestic bitch. Anim Reprod Sci., Oct 8. [Epub ahead of print], doi:10.1016/j.anireprosci.2010.08.028.

Concannon P.W., Hansel W, \& Mcentee K. (1977) Changes in LH, progesterone and sexual behavior associated with preovulatory luteinization in the bitch. Biol Reprod. 17, 604-13.

Dahlbom M., Andersson M., Vierula M., \& Alanko M. (1997) Morphometry of normal and teratozoospermic canine sperm heads using an image analyser: work in progress. Theriogenology 48, 687-698.

Davis R.O. \& Katz D.F. (1992) Standardization and comparability of CASA instruments. J Androl. 13, 81-86.

Dott H.M. \& Foster G.C. (1972) A techniques for studying the morphology of mammalian spermatozoa which are eosinophilic in a differential 'live/dead' stain. J. Reprod. Fert. 29, 443-445.

Dubiel A. (2004) Plan badania psa reproduktora w kierunku płodności. (Andrological examination of the stud dog-in polish), In Rozród psów, ed. A. Dubiel, Wydawnictwo AR, ISBN 83-89189-49-6 Wrocław, 47-65.

England G.C. \& Allen WE. (1989) Crystallization patterns in anterior vaginal fluid from bitches in oestrus. J Reprod Fertil. 86, 335-9.

England G. C. \& Concannon P.W. (2002) Determination of the Optimal Breeding Time in the Bitch: Basic Considerations. In Recent Advances in Small Animal Reproduction, Concannon P.W., England G., Verstegen J. and Linde-Forsberg C. (Eds.), International Veterinary Information Service (www.ivis.org), Document No. A1231.0602.

England G.C. \& Millar K.M. (2008) The ethics and role of AI with fresh and frozen semen in dogs. Reprod Domest Anim., 43 (Suppl 2) 165-71.

England G.C. \& Plummer J.M. (1993) Hypo-osmotic swelling of dog spermatozoa. J. Reprod. Fert. Suppl, 47, 261-270.

England G.C., Burgess C.M., Freeman S.L., Smith S.C., \& Pacey A.A. (2006) Relationship between the fertile period and sperm transport in the bitch. Theriogenology, 66, 14108.

England G.C., Allen W.E. \& Middleton D.J. (1990) An investigation into the origin of the first fraction of the canine ejaculate. Res. Vet. Sci. 49, 66-70.

Farstad W.K. (2010) Artificial insemination in dogs, In BSAVA Manual of Canine and Feline Reproduction and Neonatology, 2nd edition, England G. and von Heimendahl A. (Eds.). British Small Animal Veterinary Association ISBN 978-1905319190, Gloucester, UK.

Feldman E.C. \& Nelson R.W. (1996) Canine and Feline Endocrinology and Reproduction. W.B. Saunders Comp., ISBN 978-0721636344, Philadelphia

Ferguson J.M., Renton J.P., Farstad W. \& Douglas T.A. (1989) Insemination of beagle bitches with frozen semen. J. Reprod. Fert. Suppl. 39, 293-298. 
Fontbonne A. (2008) Ovulation, maturation ovocytaire et fecondation in vivo chez la chienne (In vivo ovulation, oocyte maturation and fertilisation in the bitch). PhD Thesis, Institut des Sciences et Industries du Vivant et de l'Environnement (Agro Paris Tech).

Fontbonne A \& Malandain E. (2006) Ovarian ultrasonography and follow-up of estrus in the bitch and queen. WALTHAM Focus 16 (2) 22-29.

Foote R.H. (2002) The history of artificial insemination: Selected notes and notables. J. Anim. Sci. 80(E. Suppl.) E22-E32

Freshman J.L. (2002) Semen Collection and Evaluation. Clinical Techniques in Small Animal Practice 17, 104-107.

Fukushima F.B., Malm C., Henry M., Gheller V.A., Serakides R., Neves M.M., Macedo S.P., Figueiredo M.S., Andrade M.E., Chaves M.S., Silva M.X., Rezende C.M. \& Melo, E.G. (2010) Site of intrauterine artificial insemination in the bitch does not affect sperm distribution within the uterus. Reprod Domest Anim. 45, 1059-1064.

Garcia-Macias V., Martinez-Pastor F., Alvarez M., Garde J.J., Anel E., Anel L. \& de Paz P. (2006) Assessment of chromatin status $\left(\mathrm{SCSA}^{\circledR}\right)$ in epididymal and ejaculated sperm in Iberian red deer, ram and domestic dog. Theriogenology 66, 1921-1930.

Garner D.L. \& Johnson L.A. (1995) Viability assessment of mammalian sperm using SYBR-14 and Propidium Iodide. Biol. Reprod. 53, 276-284.

Garner D.L., Thomas C.A., Joerg H.W., DeJarnette J.M. \& Marshall C.E. (1997) Fluorometric assessments of mitochondrial function and viability in cryopreserved bovine spermatozoa. Biol. Reprod. 57, 1401-1406.

Goodman M. (2001) Ovulation timing. Concepts and controversies. Vet. Clin. North. Am. (Small Anim. Pract.) 31, 219-235.

Gravance C.G., Garner D.L., Miller M.G. \& Berger T.(2001) Fluorescent probes and flow cytometry to assess rat sperm integrity and mitochondrial function. Reprod Toxicol. 15, 5-10.

Guérin P., Ferrer M., Fontbonne A., Bénigni L., Jacquet M., \& Ménézo Y. (1999) In vitro capacitation of dog spermatozoa as assessed by chlortetracycline staining. Theriogenology 52, 617-628.

Günzel-Apel A.R. (1994) Fertilitätskontrolle und Samenübertragung beim Hund. Enke/Gustav Fischer Verlag, ISBN 3-334-60512-4, Jena.

Günzel-Apel A.R. \& Thiet W. (1990) Intrauterine deponierung von tiefgefriersperma nach laparotomie bei einer hundin. Kleintierprax. 35, 177-180.

Hermansson U., Ponglowhapan S., Linde-Forsberg C. \& Ström-Holst B. (2006) A short sperm-oocyte incubation time ZBA in the dog. Theriogenology 66, 717-725.

Hewitt D.A. \& England G.C. (1998) An investigation of capacitation and the acrosome reaction in dog spermatozoa using a dual fluorescent staining technique. Anim. Reprod. Sci. 51, 321-332.

Hewitt D. \& England G. (2000) Assessment of optimal mating time in the bitch. In Practice 22, 24-33.

Jeffcoate I.A., Lindsay F.E.F. (1989) Ovulation detection and timing of insemination based on hormone concentrations, vaginal cytology and the endoscopic appearance of the vagina in domestic bitches. J. Reprod. Fert. Suppl. 39, 277-287.

Johnston S.D., Root Kustritz M.V., \& Olson P.N.S. (2001) Canine and Feline Theriogenology. W.B. Saunders Comp., ISBN 978-0721656076, Philadelphia

Kawakami E., Hori T. \&Tsutsui T. (1998) Changes in semen quality and in vitro sperm capacitation during various frequencies of semen collection in dogs with both asthenozoospermia and teratozoospermia. J. Vet. Med. Sci., 60, 607-614. 
Kawakami E., Morita Y., Hori T. \& Tsutsui T. (2002) Lectin-binding characteristics and capacitation of canine epididymal spermatozoa. J. Vet. Med. Sci. 64, 543-549.

Kumi-Diaka J. (1993) Subjecting canine semen to the hypo-osmotic swelling test. Theriogenology 39, 1279-1289.

Kutzler M.A. (2005) Semen collection in the dog. Theriogenology 64, 747-754.

Lévy X. \& Fontbonne A. (2007) Determining the optimal time of mating in bitches: particularities. Rev Bras Reprod Anim, 31, 128-134.

Linde-Forsberg C. (1991) Achieving canine pregnancy by using frozen or chilled extended semen. Vet. Clin. North Am. (Small Anim Pract.) 21, 467-485.

Linde-Forsberg C. \& Forsberg M (1993) Results of 527 controlled artificial inseminations in dogs. J Reprod Fert Suppl 47:313-323)

Linde-Forsberg C. (2000) Fertility data from 2041 controlled artificial inseminations in dogs. Advances in dog, Cat and Exotic Carnivore Reproduction - Book of Abstracts. Oslo, Norway. Pg 120

Linde-Forsberg C. (2002a) What Can Be Learned From 2500 AIs in the Dog? Proceedings of the 27th World Congress of WSAVA, Granada, Spain, 3-6 Oct. http://www.vin.com/proceedings/Proceedings.plx?CID=WSAVA2002\&PID=268 5

Linde-Forsberg C. (2002b) Ethical aspects of artificial insemination (AI) in the dog. Proc. 3rd EVSSAR Congress Liège, pp 41-42.

Linde-Forsberg C. (2003) Artificial Insemination in the Dog: What Can Be Learnt From Results in the Field? Proceedings of the 28th World Congress of WSAVA, Bangkok, Thailand, 24-27 Oct.

http:/ / www.vin.com/ proceedings/Proceedings.plx?CID=WSAVA2003\&PID=651 $9 \& \mathrm{O}=$ Generic

Linde-Forseberg C. \& Forsberg M. (1989) Fertility in dogs in relation to semen quality and the time and site of insemination with fresh and frozen semen. J. Reprod. Fert. Suppl., 39, 299-310.

Linde-Forsberg C., Ström Holst B., Govette G. (1999) Comparison of fertility data from vaginal vs. intrauterine insemination of frozen-thawed dog semen: a retrospective study. Theriogenology 52, 11-23.

Linde Forsberg C. (2001) Regulations and Recommendations for International Shipment of Chilled and Frozen Canine Semen. In Recent Advances in Small Animal Reproduction, Concannon P.W., England G., Verstegen J. and Linde-Forsberg C. (Eds.). International Veterinary Information Service (www.ivis.org), Document No. A1209.0501.

Linde Forsberg C. (2005a) Artificial Insemination. In ESAVS-EVSSAR Course Reproduction in companion, exotic and laboratory animal, Nantes 12th-17th September 2005. Reference 5.1 insemination.pdf)

(http://www.esavs.net/course_notes/reproduction1_05/artificial_

Linde Forsberg C. (2005b) Regulations and recommendations for international shipment of chilled and frozen canine semen. In ESAVS-EVSSAR Course Reproduction in companion, exotic and laboratory animal, Nantes 12th-17th September 2005. Reference 6.1 (http://www.esavs.net/course_notes/reproduction1_05/shipment_frozen_ canine_seme.pdf)

Lindsay F.E.F. (1983) The normal endoscopic appearance of the caudal reproductive tract of the cyclic and non-cyclic bitch: post-uterine endoscopy. J. Small Anim. Pract. 24, 115. 
Moxon R., Copley D. \& England G.C. (2010) Technical and financial evaluation of assays for progesterone in canine practice in the UK. Vet Rec. 167, 528-31.

Niżański W. (2005) Comparisons of results of intravaginal and intrauterine insemination of bitches with frozen-thawed semen. Electronic Journal of Polish Agricultural Universities 8, 4, pp.6 (http://www.ejpau.media.pl/volume8/issue4/art-12.html)

Niżański W. (2006) Intravaginal insemination of bitches with fresh and frozen-thawed semen with addition of of prostatic fluid: use of an infusion pipette and the Osiris catheter, Theriogenology 66, 470-483.

Niżański W. \& Klimowicz M. (2005) Skuteczność sztucznej inseminacji suk nasieniem świeżym przy zastosowaniu różnych metod wyznaczania terminu unasienniania (Success of artificial insemination with fresh semen with the use of different methods for determination of optimal insemination time in bitches). Medycyna Wet. $61,75-81$.

Niżański W., Klimowicz M., Partyka A., Savić M. \& Dubiel A. (2009) Effects of the inclusion of Equex STM into Tris-based extender on the motility of dog spermatozoa incubated at 5 degrees C. Reprod. Domest. Anim. 44 (Suppl. 2) 363-365.

Oettl $\square$ E.E. (1993) Sperm morphology and fertility in dog. J. Reprod. Fert., Suppl. 47, 257-260.

Olsen P.N. \& Husted P.W. (1986) Breeding management for optimal reproductive efficiency in the bitch and stud dog. In Current therapy in theriogenology. $2^{\text {nd }}$ edition, Morrow D.A. (ed), W.B. Saunbders Comp., ISBN 978-0721665801, Philadelphia, 563-466.

Pardo-Carmona B., Moyano M.R., Fernández-Palacios R. \& Pérez-Marín C.C. (2010) Saliva crystallisation as a means of determining optimal mating time in bitches. J Small Anim Pract. 51, 437-42.

Peña A.I., Johannisson A., \& Linde-Forsberg C. (2001) Validation of flow cytometry for assessment of viability and acrosomal integrity of dog spermatozoa and for evaluation of different methods of cryopreservation. J Reprod Fertil Suppl. 57, 371376.

Peña A.I., Quintela L.A., \& Herradón P.G. (1998) Viability assessment of dog spermatozoa using flow cytometry. Theriogenology 50, 1211-1220.

Petrunkina A.M., Simon K., Günzel-Apel A.R. \& Töpfer-Petersen E. (2004) Kinetics of protein tyrosine phosphorylation in sperm selected by binding to homologous and heterologous oviductal explants: how specific is the regulation by the oviduct? Theriogenology 61, 1617-1634.

Pineda M.H., Kainer R.A. \& Faulkner L.C. (1973) Dorsal median postcervical fold in the canine vagina. Am. J. Vet. Res. 34, 1487-1491.

Pinto C.R., Eilts B.E. \& Paccamonti D.L. (1998) The effect of reducing hindquarter elevation time after artificial insemination in bitches. Theriogenology. 50, 301-5.

Rijsselaere T., Van Soom A., Maes D. \&de Kruif A. (2003) Effect of technical settings on canine semen motility parameters measured by the Hamilton-Thorne analyzer. Theriogenology. 60, 1553-1568.

Rijsselaere T., Van Soom A., Van Cruchten S., Coryn M., Görtz K., Maes D. \& de Kruif A. (2004) Sperm distribution in the genital tract of the bitch following artificial insemination in relation to the time of ovulation. Reproduction 128, 801-11.

Rijsselaere T., Van Soom A., Tanghe S., Coryn M., Maes D. \&de Kruif A. (2005) New techniques for the assessment of canine semen quality: A review. Theriogenology 64, 706-719.

Root Kustritz M.V. (2003) Small animal theriogenology (The practical veterinarian). ButterworthHeinemann, ISBN 978-0750674089, Oxford, UK. 
Rota A., Iguer-Ouada M., Verstegen J. \& Linde-Forberg C. (1999a) Fertility after vaginal or uterine deposition of dog semen frozen in a TRIS extender with of without Equex STM Paste. Theriogenology 51, 1045-1058.

Rota A., Peña A.I., Linde-Forsberg C. \& Rodriguez-Martinez H. (1999b) In vitro capacitation of fresh, chilled and frozen-thawed dog spermatozoa assessed by the chloretetracycline assay and changes in motility patterns. Anim Reprod Sci. 57, 199215.

Silva L.D.M., Onclin K., Snaps F. \& Verstegen J. (1995) Laparoscopic intrauterine insemination in the bitch. Theriogenology 43, 615-623.

Silva L.D.M., Onclin K., Lejeune B. \& Verstegen J.P. (1996) Comparisons of intravaginal and intrauterine insemination of bitches with fresh or frozen semen. Vet. Rec. 17, 154157.

Silva P.F. \& Gadella B.M. (2006) Detection of damage in mammalian sperm cells. Theriogenology 65, 958-978.

Sirivaidyapong S., Cheng F.P., Marks A., Voorhout W.F., Bevers M.M. \& Colenbrander B. (2000) Effect of sperm diluents on the acrosome reaction in canine sperm. Theriogenology 53, 789-802.

Ström-Holst B., Larsson B., Rodriguez-Martinez H., Lagerstedt A.-S. \& Linde-Forsberg C. (2001). Zona pellucida binding assay- a method for evaluation of canine spermatozoa. J. Reprod. Fertil. Suppl 57: 137-140

Thomassen R. \& Farstad W. (2009) Artificial insemination in canids: a useful tool in breeding and conservation. Theriogenology, 71, 190-199.

Thomassen R., Sanson G., Krogenæs A., Fougner J.A., Andersen Berg K. \& Farstad W. (2006) Artificial insemination with frozen semen in dogs: A retrospective study of 10 years using a non-surgical approach. Theriogenology 66, 1645-1650.

Tsutsui T. (1989) Gamete physiology and timing of ovulation and fertilization in dogs. J Reprod Fertil Suppl. 39, 269-75.

Tsutsui T., Takahashi F., Hori T., Kawakami E. \& Concannon P.W. (2009) Prolonged duration of fertility of dog ova. Reprod Domest Anim. 44 Suppl 2, 230-3.

Verstegen J., Iguer-Ouada M. \& Onclin K. (2001) Computer assisted semen analyzers in andrology research and veterinary practice. Theriogenology 57, 149-179.

Wallace S.S., Mahaffey M.B., Miller D.M. Thompson F.N. \& Chakraborty P.K. (1992) Ultrasonographic appearance of the ovaries of dogs during the follicular and luteal phases of the estrous cycle. Am J Vet Res 53(2): 209-215.

Watson P.F. (1975) Use of Giemsa stain to detect changes in acrosomes of frozen ram spermatozoa. Vet. Rec. 97, 12-15.

Wilson M.S. (1993) Non-surgical intrauterine artificial insemination in bitches using frozen semen. J. Reprod. Fert. Suppl. 47, 307-311.

Wilson M.S. (2001) Transcervical insemination techniques in the bitch. Vet. Clin. North. Am. (Small Anim. Pract.) 31, 291-304.

Yeager A.E. \& Concannon P.W. (1996) Ovaries. In: Small animal ultrasound, Green RW (Ed.), Philadelphia: Lippincott Raven, 293-303. 


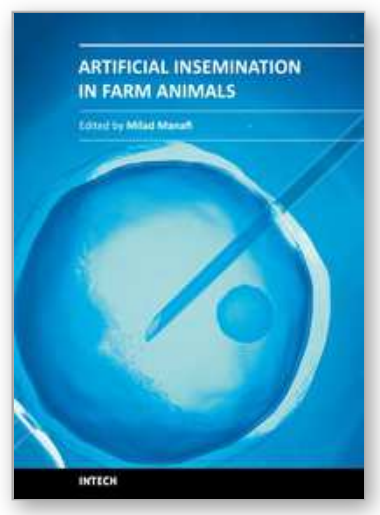

\author{
Artificial Insemination in Farm Animals \\ Edited by Dr. Milad Manafi
}

ISBN 978-953-307-312-5

Hard cover, 300 pages

Publisher InTech

Published online 21, June, 2011

Published in print edition June, 2011

Artificial insemination is used instead of natural mating for reproduction purposes and its chief priority is that the desirable characteristics of a bull or other male livestock animal can be passed on more quickly and to more progeny than if that animal is mated with females in a natural fashion. This book contains under one cover 16 chapters of concise, up-to-date information on artificial insemination in buffalos, ewes, pigs, swine, sheep, goats, pigs and dogs. Cryopreservation effect on sperm quality and fertility, new method and diagnostic test in semen analysis, management factors affecting fertility after cervical insemination, factors of noninfectious nature affecting the fertility, fatty acids effects on reproductive performance of ruminants, particularities of bovine artificial insemination, sperm preparation techniques and reproductive endocrinology diseases are described. This book will explain the advantages and disadvantages of using Al, the various methodologies used in different species, and how Al can be used to improve reproductive efficiency in farm animals.

\title{
How to reference
}

In order to correctly reference this scholarly work, feel free to copy and paste the following:

Rita Payan-Carreira, Sonia Miranda and Wojciech Nizanski (2011). Artificial Insemination in Dogs, Artificial Insemination in Farm Animals, Dr. Milad Manafi (Ed.), ISBN: 978-953-307-312-5, InTech, Available from: http://www.intechopen.com/books/artificial-insemination-in-farm-animals/artificial-insemination-in-dogs

\section{INTECH}

open science | open minds

\section{InTech Europe}

University Campus STeP Ri

Slavka Krautzeka 83/A

51000 Rijeka, Croatia

Phone: +385 (51) 770447

Fax: +385 (51) 686166

www.intechopen.com

\section{InTech China}

Unit 405, Office Block, Hotel Equatorial Shanghai

No.65, Yan An Road (West), Shanghai, 200040, China

中国上海市延安西路65号上海国际贵都大饭店办公楼 405 单元

Phone: +86-21-62489820

Fax: $+86-21-62489821$ 
(C) 2011 The Author(s). Licensee IntechOpen. This chapter is distributed under the terms of the Creative Commons Attribution-NonCommercialShareAlike-3.0 License, which permits use, distribution and reproduction for non-commercial purposes, provided the original is properly cited and derivative works building on this content are distributed under the same license. 